\title{
Odpowiedzialność karnoskarbowa za zajmowanie się sprawami finansowymi innej osoby
}

Penal and fiscal liability for managing other person's financial matters

\section{Wprowadzenie}

Prawo karne skarbowe regulując zachowania zgodne z szeroko rozumianym prawem finansowym, podkreśla swoją autonomiczność przy zachowaniu spójności systemowej prawa karnego. Co do istoty prawo karne skarbowe jednak różni się od prawa karnego powszechnego $\mathrm{z}$ uwagi na nierozerwalnie $\mathrm{z}$ nim połączoną cechę blankietowości norm. Specyfika ta wynika z łączenia prawa karnego z innymi dziedzinami i ma za zadanie ochronę przestrzegania zasad innych gałęzi prawa. Powstaje przy tym problematyka związana z normami, do których należy się odwołać przy odczytywaniu dyspozycji norm prawa karnego skarbowego. Mają one chronić interesy finansowe państwa, temu też podporządkowana jest możność stosowania represji karnej, jaka ciąży na podatniku. Ryzyko odpowiedzialności karnej dotyka również osobę, która nie jest podatnikiem, ale odpowiada w imieniu własnym za wywiązywanie się z obowiązków podatnika na podstawie obowiązującego powszechnie prawa, aktu indywidualnego lub określonego oświadczenia woli.

\section{Odpowiada jak sprawca}

Dopuszczenie się czynu zabronionego musi spotkać się z odpowiednią reakcją państwa zapewniającego spełnianie funkcji sprawiedliwościowej, ochronnej czy gwarancyjnej prawa karnego. Kodeks karny skarbowy (dalej: k.k.s.) (Ustawa, 
1999, art. 54, §1) penalizuje m.in. uchylanie się od opodatkowania podatnika narażającego podatek na uszczuplenie. W słowniczku pojęć ujętym w art. 53 k.k.s. nie znajdzie się rozstrzygnięcia, co ustawodawca rozumie pod pojęciem podatnika, podobnie w przypadku interpretacji terminu „podatek”, do których wprost odnosi się ten przepis. W art. $53 \S 30$ k.k.s. ujęto, że użyte w części szczególnej kodeksu oba te określenia mają znaczenie nadane im w ordynacji podatkowej z pewnymi zastrzeżeniami, o których mowa w art. $53 \$ 30$ pkt 1 i 2 k.k.s. Gdyby przyjąć dyrektywę interpretacyjną zgodnie z wykładnią językową, wynik byłby następujący: podatnikiem jest osoba zobowiązana do płacenia podatków (SJP, 2020, Podatnik), podatkiem zaś jest obowiązkowe świadczenie materialne pobierane przez państwo w celu pokrycia jego wydatków (SJP, 2020, Podatek). Tymczasem ustawodawca w ordynacji podatkowej pod wymienionymi kategoriami definiuje znacznie więcej. Zgodnie $\mathrm{z}$ art. 6 tej ustawy podatkiem jest publicznoprawne, nieodpłatne, przymusowe oraz bezzwrotne świadczenie pieniężne na rzecz Skarbu Państwa, województwa, powiatu lub gminy, wynikające z ustawy podatkowej. Podatnikiem jest na podstawie art. 7 ordynacji osoba fizyczna, osoba prawna lub jednostka organizacyjna niemająca osobowości prawnej, podlegająca na mocy ustaw podatkowych obowiązkowi podatkowemu. Obowiązkiem jest wynikająca z tych aktów normatywnych nieskonkretyzowana powinność przymusowego świadczenia pieniężnego w związku z zaistnieniem zdarzenia określonego w tych ustawach. Pojęcia te są zatem szersze w ujęciu ustawowym, co ma swoje dalsze konsekwencje w postaci powstawania konkretnych zobowiązań podatnika, płatnika czy innych obowiązanych osób.

Instytucja odpowiedzialności reprezentanta została wprowadzona w życie wraz z uchwaleniem obowiązującego k.k.s. Wcześniej brakowało normatywnej regulacji tej problematyki, chociaż konieczność stosowania odpowiedzialności reprezentanta nie była sporna. Ustawodawca uzasadniał wprowadzenie nowej instytucji tym, że w części szczególnej podmiot wielu przestępstw skarbowych i wykroczeń skarbowych jest określony kolektywnie (zbiorowo), np. „rezydent” czy też „podatnik” lub „płatnik” (jako osoba prawna lub jednostka organizacyjna niemająca osobowości prawnej). Jest to uzupełnienie typowych postaci sprawstwa z części ogólnej, specjalnej konstrukcji sprawstwa (sui generis) przewidzianej $\mathrm{w}$ ramach czterech grup rodzajowych wykroczeń skarbowych. Tyczą się one niedopełnienia obowiązku nadzoru nad przestrzeganiem reguł obowiązujących w działalności danego przedsiębiorcy i dopuszczenia się przez to, chociażby nieumyślnie, dokonania czynu zabronionego określonego w odnośnych rozdziałach ustawy (Uzasadnienie, 1999, s. 17). W tym zakresie sprawca to osoba niedopełniająca obowiązku nadzoru. Czyny, do których odnosi się prawodawca, 
określone zostały w rozdziałach 6-9 k.k.s. To rzadki w polskim prawie karnym typ czynu zabronionego odnoszący się do wadliwego wykonywania obowiązków nadzoru polegającego na kontroli przestrzegania reguł, przez co należy rozumieć zasady wynikające z obowiązujących przepisów prawa podatkowego lub prawa finansów publicznych (Konarska-Wrzosek, Oczkowski, Skorupka, 2012, s. 297).

Zgodnie $\mathrm{z}$ art. $9 \$ 3$ k.k.s. za przestępstwa skarbowe lub wykroczenia skarbowe odpowiada - jak sprawca - także ten, kto na podstawie przepisu prawa, decyzji właściwego organu, umowy lub faktycznego wykonywania zajmuje się sprawami gospodarczymi, w szczególności finansowymi, osoby fizycznej, osoby prawnej albo jednostki organizacyjnej niemającej osobowości prawnej. Przepis ten uzyskał aktualne brzmienie w drodze nowelizacji z 2005 r. (Ustawa, 2005, art. 1 pkt 5), która zakładała uczynienie go bardziej dokładnym i zrozumiałym dla jego adresatów, nie zawężając pola kryminalizacji, akcentując typowy charakter więzi łączącej określone podmioty. Intencją tego specjalnego sprawcy nie jest tutaj jakiekolwiek naruszenie zasad racjonalnego gospodarowania, lecz tylko zamach na konkretną sferę interesów finansów publicznych (Uzasadnienie, 2003, s. 103). Artykuł $9 \$ 3$ k.k.s. nie przewiduje odrębnej formy zjawiskowej sprawstwa w prawie karnym skarbowym. Statuuje szczególną podstawę przypisania odpowiedzialności karnej. Nie tworzy się tu odrębnego typu odpowiedzialności, lecz w sposób jednoznaczny umożliwia się przypisanie sprawstwa osobie fizycznej zajmującej się sprawami gospodarczymi innego podmiotu (Nalikowski, 2011, s. 95-103). Zgodnie z art. $9 \$ 2$ k.k.s. każdy ze współsprawców wykonujących czyn zabroniony odpowiada w granicach swej umyślności lub nieumyślności, niezależnie od odpowiedzialności pozostałych sprawców. Sprawcą czynu może być niewątpliwie osoba, na której spoczywa określony obowiązek fiskalny. Ustawodawca, uwzględniając specyfikę prawa karnego skarbowego i jego przedmiot ochrony, uznał, że znamiona czynu może zrealizować osoba, która co prawda sama nie jest zobowiązana do przestrzegania obowiązków fiskalnych wprost, np. nie jest podatnikiem czy płatnikiem, jednak z uwagi na szczególne jej położenie, uprawnienia i działania może odpowiadać za czyny zabronione jak sprawca.

Jest to model akcesoryjnej odpowiedzialności karnej. Ustawodawca zasadnie przyjął, że współdziałająca osoba winna odpowiadać za udział w cudzym czynie zabronionym. Odpowiedzialność współsprawcy uzależniona jest popełnieniem przestępstwa przez sprawcę (Tyszkiewicz, 1964, s. 65-66). Współdziałający odpowiada w takim zakresie, w jakim doszło do naruszenia dobra prawnego. Artykuł 20 Kodeksu karnego (dalej: k.k.) określający niezależną odpowiedzialność współdziałających oraz dalsze normy objęte art. $21 \S 2$ i 3 k.k. odnoszące się do indywidualizacji odpowiedzialności karnej odpowiednio znajdują zastosowanie 
w stosunku do przestępstw skarbowych na podstawie art. $20 \$ 2$ k.k.s. (Ustawa, 1997, art. 20, 21). Każdy ze współdziałających w popełnieniu czynu zabronionego odpowiada w granicach swojej umyślności lub nieumyślności niezależnie od odpowiedzialności pozostałych współdziałających. Przyjmuje się pogląd o formalno-obiektywnej i restryktywnej charakterystyce instytucji sprawstwa czynu zabronionego (Dębski, 2013, s. 895-908), który zakłada, że można wyróżnić tylko cztery ustawowo stypizowane postaci sprawstwa pojedynczego, współsprawstwa, sprawstwa polecającego i sprawstwa kierowniczego. Istotę sprawstwa określa władztwo (Tatherrschaft) sprawcy nad wypełnieniem znamion czynu, które przejawiają się tym, że jest on rezultatem własnego i samodzielnego zachowania się (Zawłocki, 2013, s. 212). Władztwo w tym sensie oznacza pełną kontrolę sprawcy, czyli zachowanie własne, świadome i samodzielne, chociaż nie musi być ono wykonywane na swoją rzecz, może być w interesie osoby trzeciej, co nie zmienia charakteru czynu tej osoby, ponieważ sprawca działający na rzecz innej osoby nadal wypełnia znamiona czynu, dokonuje czynu zabronionego samodzielnie, osobiście. Ograniczając skrajną akcesoryjność, której ujęcie oznaczało odpowiedzialność współsprawców jako biorących udział w cudzym czynie zabronionym, przyjęto ideę sprawstwa pośredniego (mittelbare Täterschaft) odwołującego się do ustalenia, że sprawca pośredni sam nie wypełnia znamion czynu zabronionego, ale działa poprzez inną osobę (durch einen anderen) niebędącą sprawcą, łącząc tym samym sprawcę z czynem. Odpowiedzialność sprawcy pośredniego może jednak wynikać ze szczególnego przepisu ustanawiającego warunki tej odpowiedzialności, a jest nim art. $9 \$ 3$ k.k.s.

Odpowiedzialność, o której tu mowa, dotyczy reprezentantów, czyli osób fizycznych zdolnych do ponoszenia odpowiedzialności penalnej z uwagi na reprezentowanie przez nią innej osoby i to bez względu na źródło umocowania do reprezentacji. Ustawowe kryteria odpowiedzialności „jak sprawca” nie oznaczają przy tym, że jest to odpowiedzialność zastępcza czy odpowiedzialność posiłkowa zamiast kogoś (tu w domyśle reprezentowanego). Jest ona związana z działaniem za inną osobę przy popełnieniu czynu zabronionego. Odpowiedzialność w tym przypadku jest rezultatem zachowania reprezentanta, które wyraża skutki dla reprezentowanego. Jest to zachowanie, które faktycznie nie jest ani zachowaniem (działalnością) podmiotu reprezentowanego, ani też czynem osoby fizycznej działającej we własnym imieniu i na własną rzecz, traktowanym jako czyn, którego popełnienie wypełnia warunki odpowiednie dla ogólnych typowych podstaw odpowiedzialności karnej (sprawstwa), a jest faktycznym zachowaniem tej osoby, które jest karnoprawnie relewantne, ponieważ wypełnia ustawowe znamiona typu czynu zabronionego pod groźbą kary (Zawłocki, 2013, s. 8-9, 68). Ustawo- 
dawca przyjął model, w którym znamiona czynu indywidualnego, możliwego do popełnienia przez osobę posiadającą odpowiednią właściwość (np. bycie podatnikiem), są spełnione zastępczo za reprezentowanego przez osobę prowadzącą jego sprawy, co na gruncie k.k.s. jest jego własnym czynem, chociaż nie mieści się w granicach odpowiedzialności prawa finansowego, a nawet nie jest adresatem obowiązków, co do których naruszenia jego odpowiedzialność jest możliwa. Nie zachodzi tożsamość czynu między sprawcą będącym reprezentantem a sprawcą będącym reprezentowanym. Ustawowa klauzula odpowiedzialności „jak sprawca” (można również określić „jako sprawca”) wskazuje na tę okoliczność, uwypuklając fakt reprezentowania stanowiący wyraz faktycznego zachowania osoby zajmującej się cudzymi sprawami, działając w jej imieniu. Nie dochodzi także do tożsamości podstawy normatywnej odpowiedzialności tych osób. Jak wskazuje R. Zawłocki, brak ustawowo określonej klauzuli odpowiedzialności reprezentanta w odniesieniu do danego przestępstwa stanowi formalną przeszkodę w pociągnięciu go do odpowiedzialności karnej w przypadku, gdy czyn został popełniony w związku z reprezentacją określonej osoby i jego działalnością (Zawłocki, 2013, s. 10). Podobny model odpowiedzialności ustawodawca przewiduje w art. 308 k.k. ustanawiającym regułę odpowiedzialności jak dłużnik lub wierzyciel tego, kto na podstawie przepisu prawnego, decyzji właściwego organu, umowy lub faktycznego wykonywania zajmuje się sprawami majątkowymi innej osoby prawnej, fizycznej, grupy osób lub podmiotu niemającego osobowości prawnej. Podstawową funkcją klauzuli zawartej w art. 308 k.k. jest rozszerzenie zakresu kryminalizacji na przestępstwa indywidualne dłużników i wierzycieli (Wyrok SA, II AKa 176/12), jest to klauzula odpowiedzialności zastępczej (Wyrok, II AKa 101/12). W przypadkach obu przepisów karnych sprawstwo reprezentanta opiera się w rzeczywistości na odrębnych od pozostałych przepisów prawa karnego regułach, spośród których najważniejszym kryterium jest zajmowanie się sprawami gospodarczymi podmiotu „popełniającego czyn zabroniony”.

\section{Kto na podstawie przepisu prawa, decyzji, umowy lub faktycznego wykonywania}

Ustawodawca w art. $9 \$ 3$ k.k.s. przyjął odpowiedzialność osoby zajmującej się cudzymi sprawami jako klauzulę generalną odnoszącą się do wszystkich typów czynów zabronionych ustawowo. W prawie karnym skarbowym w pierwszym rzędzie chodzi bardziej o egzekwowanie należności publicznoprawnych i wyrównywanie uszczerbku finansowego Skarbu Państwa niż o represję (Wilk, 
Zagrodnik, 2019, s. 7). Na dalszy plan, chociaż nie mniej istotny, schodzi funkcja represyjno-sprawiedliwościowa odpowiedzialności, decydująca o tym, że wobec dokonania czynu zabronionego represja karna ma zaspokoić poczucie sprawiedliwości w znaczeniu indywidualnym pokrzywdzonego, jak i ogólnym, społecznym. Intencje ustawodawcy co do określenia katalogu osób mogących ponosić odpowiedzialność odnoszą się do umożliwienia karania nie tylko tej osoby, która bezpośrednio dopuściła się czynu, lecz także do osób, które miały wpływ na dokonanie czynu, niejako dokonując go w imieniu sprawcy, o którym mowa w ostatniej części odnośnego przepisu.

Na gruncie k.k.s. odpowiedzialność tyczy się podmiotu sprawczego zgodnego z terminologią ustaw finansowych, np. podatnika, płatnika, producenta, importera czy nawet rezydenta, którymi w każdym przypadku są konkretne osoby. Osoba prawna nie może być podmiotem postępowania karnoskarbowego, nawet kiedy na gruncie ustawy podatkowej materialnej jest podatnikiem. Podobnie ma się sytuacja w odniesieniu do jednostek organizacyjnych niemających osobowości prawnej (spółki osobowe, wspólnota mieszkaniowa). Odpowiedzialność można przypisać jedynie osobie fizycznej będącej określonym organem osoby prawnej albo pełniącej określoną funkcję w ramach osoby prawnej (Wyrok WSA, I SA/ Wr 643/13; Wyrok SN, IV KK164/02; Wyrok WSA I SA/Wr 941/12). W przypadku osoby prawnej organami mogą być zarząd, rada nadzorcza, zgromadzenie wspólników lub zgromadzenie akcjonariuszy. Poszerzona odpowiedzialność tych osób wynika z przepisów prawa i można jasno określić jej ramy. Struktura osoby prawnej może być jednak bardziej skomplikowana i powoływać do wykonywania lub nadzoru nad sprawami gospodarczymi (finansowymi) osoby o różnych kompetencjach, chociażby dyrektor, księgowy, doradca podatkowy czy analityk. Na gruncie art. $9 \$ 3$ k.k.s. Sąd Najwyższy uznał, że spółka cywilna nie należy do jednostek organizacyjnych niemających osobowości prawnej wymienionych w tym artykule, gdyż nie posiada zdolności prawnej w rozumieniu prawa cywilnego (Uchwała SN, I KZP 7/07). Spółka cywilna funkcjonalnie spełnia jedynie przesłankę jednostki organizacyjnej tworzącej zbiorczą nazwę podmiotów, które nie są osobami prawnymi, stanowi pewną organizację wspólników utworzoną na mocy ustawy, jednak nie mieści się w ramach reżimu odpowiedzialności opisanej w art. $9 \$ 3$ k.k.s. Pogląd ten został zaaprobowany w piśmiennictwie (Mering, 2007, s. 135-142). Na potrzeby podatku od towarów i usług spółka cywilna jednak jest podatnikiem, a zatem to na spółce ciążą obowiązki określone ustawą VAT, co jasno dowodzi skomplikowania odnośnej tematyki.

Zgodnie z ordynacją podatkową osoby prawne oraz jednostki organizacyjne niemające osobowości prawnej, będące płatnikami lub inkasentami, są zobowią- 
zane wyznaczyć osoby, do których obowiązków należy obliczanie i pobieranie podatków oraz terminowe wpłacanie organowi podatkowemu pobranych kwot, a także zgłosić właściwemu miejscowo organowi podatkowemu te osoby (Ustawa, 1997, art. 31). Wyznaczenie to jest zajmowaniem się sprawami gospodarczymi, o którym mowa w art. $9 \$ 3$ k.k.s. Zajmowanie się sprawami na podstawie przepisu prawa odnosi się do każdego aktu prawnego, na podstawie którego powołuje się określoną osobę lub kategorie osób spełniających określone kryteria. Nie ma tu znaczenia, czy jest to przepis rangi konstytucyjnej, ustawowej, rozporządzenia czy aktu prawa miejscowego. Umocowanie do zajmowania się sprawami w akcie prawnym (np. Kodeksie spółek handlowych), decyzji właściwego organu (np. orzeczenia sądu, decyzji zarządu osoby prawnej, władz samorządowych, uchwały wspólników, decyzji syndyka masy upadłościowej ustanowionego przez sąd) ma znaczenie odgórne, nie jest zależne jedynie od decyzji samej osoby zajmującej się w czyimś imieniu jej sprawami. Inaczej jest w przypadku podstawy umownej (np. umowy o pracę, o dzieło, zlecenia czy kontraktu menedżerskiego), która w swojej treści reguluje kwestię przyjętych praw i obowiązków, ponadto winna ustanawiać ich granice. Wymienione podstawy są o tyle klarowne, że przybierają formę zmaterializowaną, czyli taką, do której można sięgnąć w celu rozstrzygnięcia wątpliwości co do praw i obowiązków związanych z zajmowaniem się sprawami innej osoby czy innych okoliczności. Dochodzi tu do formalnego przekazania uprawnień, obowiązków i przyjęcia ich przez określoną osobę np. poprzez wyrażenie zgody na pełnienie określonej funkcji, zawarcie umowy czy przyjęcie pełnomocnictwa. Nie ma przy tym obowiązku informowania czy pouczania o ciążącej odpowiedzialności. Osoba przyjmująca na siebie sprawy innej osoby jest zobowiązana do przestrzegania prawa w granicach wykonywanych przez siebie czynności, do czego zaliczyć należy także powzięcie wiedzy o odpowiedzialności, jaka powstaje w związku z przyjęciem na siebie pewnych obowiązków.

Problematyczne może być rozstrzygnięcie o odpowiedzialności osób, które prowadzą sprawy, nie będąc jednocześnie podmiotem profesjonalnie trudniącym się tego rodzaju sprawami innej osoby bez określonej podstawy. Mowa tu o sytuacjach braku zmaterializowanego umocowania w tym zakresie przy faktycznym ich prowadzeniu. Podstawa ta jest najtrudniejsza do dookreślenia, ponieważ de facto nie ma tu katalogu wypełniającego opisywane kryteria, należy przyjąć, że chodzi tu o wszystkie te sytuacje, w których określona osoba bez oparcia w tytule prawnym zajmuje się sprawami gospodarczymi, finansowymi innej osoby podlegającej obowiązkom wynikającym z prawa finansowego. Ustawodawca nie stworzył zamkniętego katalogu osób mogących ponosić odpowiedzialność 
w tego rodzaju przypadkach, nie ustanowił też odrębnego reżimu i struktur odpowiedzialności w zależności od podstawy przyjęcia zajmowania się sprawami finansowymi innej osoby. Osoba objęta dyspozycją opisywanego przepisu stoi na takiej samej pozycji jak osoba, na rzecz której działa, grozi jej również taka sama sankcja karna. Ustawodawca przyjął kryterium faktycznego wykonywania spraw gospodarczych, w szczególności finansowych. Nie zawężono tej odpowiedzialności do wewnętrznej czy zewnętrznej struktury sprawcy, np. pracownika czy stałego współpracownika. Za przykład niech posłuży osoba zajmująca się obsługą księgową podatnika, w tym sporządzaniem deklaracji lub oświadczeń składanych organowi podatkowemu, która może ponosić odpowiedzialność karną jak sprawca (podatnik) - z art. $56 \$ 1$ k.k.s. - jeżeli podając w tych dokumentach nieprawdę lub zatajając prawdę, naraziła podatek na uszczuplenie (Wyrok SN, V KK158/13).

Nie musi to być zawodowe prowadzenie spraw, odpowiedzialność nie sprowadza się wyłącznie do prawników czy księgowych. Wręcz przeciwnie, nie ma żadnego katalogu ograniczającego w tym zakresie. Odpowiedzialność spoczywa na osobach, które świadomie przyjęły na siebie obowiązki prowadzenia spraw finansowych. Kryteria faktycznego zajmowania się sprawami spełnia prowadzenie cudzych spraw bez zlecenia, a więc instytucja opisana w art. 752 i nast. Kodeksu cywilnego (dalej: k.c.), czy z uprzejmości lub pomocy bezinteresownej. Posiłkowo można przytoczyć art. 752 k.c. wskazujący na konieczność prowadzenia sprawy z korzyścią dla osoby, której ona dotyczy, z jej prawdopodobną wolą oraz przy zachowaniu należytej staranności. Obowiązki osoby prowadzącej sprawy powinny być określone, aby w ogóle mówić o kwestii faktycznego ich wykonywania w zgodzie między osobą wykonującą a zlecającą. Żona, która pomaga swojemu mężowi w prowadzonej przez niego działalności gospodarczej, prowadząc jego księgowość oraz rozliczenia finansowe z kontrahentami, nie jest wyłączona spod odpowiedzialności. Decydujące jest łączne spełnienie kryteriów przyjęcia obowiązków przez reprezentanta osoby zobowiązanej do przestrzegania norm prawa finansowego oraz niewywiązanie się lub nieprawidłowe wywiązanie się z nich przez tę osobę trzecią, przez co spełnione zostały przesłanki określonego przepisu k.k.s.

Przyjęty model nie wyłącza odpowiedzialności nawet mimo braku umowy odnoszącej się do określenia rodzaju prowadzonych spraw, praw i obowiązków, procedury czy rygoru odnoszącego się do zabezpieczenia interesów powierzającego w celu prawidłowego wykonania umowy. Dalej odpowiedzialność kształtuje się podobnie wobec braku udzielenia pełnomocnictwa będącego węzłem prawnym, którego rozwiązanie i płynące z tego konsekwencje jest prostsze niż w przypad- 
ku kontraktu. Sąd Najwyższy rozstrzygnął kwestię braku zmaterializowanej podstawy zajmowania się sprawami finansowymi, uznając, że zobowiązanie do wykonywania czynności stanowiących treść funkcji płatnika wynikać może z treści jakiejkolwiek czynności wyrażającej wolę uprawnionego, jeżeli wskazuje osobę zobowiązaną oraz określa zakres powierzonych jej obowiązków w sposób pozwalający przyjąć, że wykonywać ma czynności płatnika (Postanowienie SN, I KZP 26/98). Istota tego orzeczenia odnosi się nie tylko do obowiązków płatnika, jest ona równie zasadna w przypadku innych obowiązków znajdujących oparcie w przepisach podatkowych.

Działanie musi być w interesie, w imieniu reprezentowanego. Wówczas w grę będzie wchodziła owa rozszerzona subsydiarna odpowiedzialność karna. Subsydiarność należy odczytywać zgodnie z art. $9 \$ 3$ k.k.s. z konkretnym przepisem szczególnym ustanawiającym znamiona czynu. Instytucja opisana w odnośnej normie części ogólnej nie stanowi sprawstwa zastępczego. To, że ktoś zastępuje inną osobę, wypełniając deklarację podatkową i przekazując ją podatnikowi do podpisu, nie stanowi o wyłącznej odpowiedzialności tego zastępującego przy abstrahowaniu od odpowiedzialności podatnika, którego to zachowanie, np. podpisanie i złożenie nierzetelnej deklaracji mającej dalsze skutki podatkowe w postaci narażenia podatku na uszczuplenie, determinuje sprawstwo podatnika, lecz także zachowanie osoby wypełniającej ową deklarację może wypełniać znamiona czynu zabronionego. Nie ma wyodrębnionej formy zjawiskowej sprawstwa czy quasi-sprawstwa osoby prowadzącej sprawy podatnika.

Podstawą odpowiedzialności karnoskarbowej znajdującej oparcie w opisywanej instytucji jest zajmowanie się sprawami na podstawie którejś z czterech kategorii: przepisu prawa, decyzji właściwego organu, umowy, faktycznego wykonywania. Katalog ten jest zamknięty i wypełnia wszelkie warianty prowadzenia spraw w cudzym imieniu. Zasady te współgrają z ogólną formułą odpowiedzialności, która zgodnie $\mathrm{z}$ art. $1 \S 3$ k.k.s. brzmi, że nie popełnia przestępstwa skarbowego lub wykroczenia skarbowego sprawca czynu zabronionego, jeżeli nie można mu przypisać winy w czasie czynu (nullum crimen, nulla contraventio sine culpa). Aby przyjąć obiektywną zdolność do zachowania się zgodnie z prawem, konieczne jest ustalenie, że przed tym zachowaniem sprawca zadbał w należyty sposób o utrzymanie gotowości do realizacji normy na prawnie wymaganym poziomie (Majewski, 2002, s. 176 nn.). Przypisanie sprawcy winy, a zatem personalna zarzucalność popełnienia czynu, jest warunkiem, aby można było mówić o indywidualnej odpowiedzialności. Sam fakt naruszenia normy prawnej ugruntowanej w prawie finansowym i penalizowany w k.k.s. nie jest wystarczający, konieczne jest przypisanie winy, które musi uwzględniać takie 
okoliczności jak: wiek, poczytalność, świadomość karalności czynu oraz błąd co do bezprawności określonego zachowania. Idea odpowiedzialności za zajmowanie się sprawami innej osoby kładzie nacisk na pewien szczególny rodzaj winy związany z brakiem samodzielnego wykonywania czynności, mianowicie na winę w wyborze (culpa in eligendo) i winę odnoszącą się do nadzoru (culpa in custodiendo). Skoro bowiem określona osoba podejmuje czynności w cudzym interesie, to osoba, na rzecz której działanie jest podejmowane, zobowiązana jest do rzetelności w zakresie doboru osoby, której wyznacza te czynności, oraz właściwego dozoru nad tą osobą. Chociaż ustawodawca nie przyjął normatywnych dyrektyw spełnienia kryteriów quasi-winy, to niewątpliwie regulacja art. $9 \$ 3$ k.k.s. opiera się na tej konstrukcji winy wiążącej zachowanie jednej osoby z odpowiedzialnością drugiej.

\section{Zajmuje się sprawami gospodarczymi, w szczególności finansowymi}

Osoba fizyczna, na której ciąży prawny obowiązek, odpowiada za czyny zabronione jako sprawca. Istota tej normy odnosi się do relacji faktycznie podejmowanych zachowań reprezentanta, stanowiących znamiona sprawcze strony przedmiotowej normatywnie ujętego czynu zabronionego. Jednak fakt, że np. podatnikiem jest osoba fizyczna (niezależnie czy dotyczy to jej działalności zawodowej czy też nie), nie wyklucza odpowiedzialności osób, które zajmują się jego sprawami powierzonymi przez nią do prowadzenia. Rodzaj i zakres odpowiedzialności powiązane są z charakterystyką podejmowanych faktycznie czynności i ich skutków na gruncie praw i obowiązków sprawcy. Mowa tu zatem o tym, że zajmowanie się sprawami finansowymi powinno zostać powierzone przez akt władczy (przepis prawa, decyzja organu rozumianego jako osoba trzecia, nie organ jako część organizacyjna adresata normy prawa finansowego) lub przez samego zainteresowanego (lub jego organ w znaczeniu organizacyjnym) i przyjęte przez osobę trzecią, ponieważ odnośne reguły dotyczą działania w cudzym interesie. W przeciwnym przypadku nie dojdzie do spełnienia ustawowej przesłanki faktycznego zajmowania się tego rodzaju sprawami i wobec braku konsensusu stron co do zakresu prowadzenia spraw (skutkującego brakiem powierzenia lub nieprzyjęciu spraw) braku odpowiedzialności karnoskarbowej. Co więcej, nie każde prowadzone sprawy będą narażały na represję karną, a jedynie te, które są sprawami gospodarczymi, w tym finansowymi. Pojęcia te należy odczytywać jako wszelkiego rodzaju czynności prawne i faktyczne, które są podejmowane 
w związku z działalnością podmiotu. Zajmowanie się sprawami gospodarczymi to wszystkie czynności faktyczne i prawne, podejmowane w związku z działalnością tej jednostki, a dotyczące sfery gospodarczej, tzn. sfery organizacji oraz wymiany dóbr i usług (Kotowski, Kurzępa, 2006, s. 45; Tatarczak, P., Tatarczak, J., 2002, s. 24-28). Sprawcą przestępstwa może być m.in. doradca podatkowy zajmujący się - na podstawie umowy - sprawami gospodarczymi klienta, także prowadzenie ksiąg rachunkowych przez doradcę podatkowego wyczerpuje znamię zajmowania się sprawami gospodarczymi (Wyrok SN, III KK 213/05). Prowadzeniem spraw gospodarczych, w tym w szczególności finansowych, może być prowadzenie wszelkiego rodzaju ksiąg, naliczanie, potrącanie i odprowadzanie podatków jako płatnik lub podatnik. Karalnym zachowaniem może być np. nieujawnienie właściwemu organowi podatkowemu przedmiotu i podstawy opodatkowania z tytułu nabycia towaru lub świadczenia usług, co prowadzi do narażenia podatku na uszczuplenie. Osoba faktycznie zajmująca się sprawami gospodarczymi, w tym finansowymi, musi demonstrować zachowanie odpowiadające zespołowi znamion opisujących określony typ czynu zabronionego stanowiącego przestępstwo lub wykroczenie skarbowe, uczestniczyć w sprawach gospodarczych. Przypisanie odpowiedzialności zależy jednak od świadomości tej osoby przy wypełnianiu swoich obowiązków. Faktycznie mogą przybierać postać technicznych czynności, prostych działań rachunkowych, co jednak nie zmienia reguł odpowiedzialności. Nie sposób przy tym przypisać odpowiedzialności osobie w sytuacji, w której nie posiada ona wiedzy o tym, że podejmowane przez nią czynności mające znaczenie na gruncie prawa finansowego spełniają przesłanki czynu zabronionego, np. uszczuplając należność publicznoprawną.

$Z$ drugiej strony ryzyko powstania odpowiedzialności de facto spoczywa na podatniku, który powierza prowadzenie spraw innej osobie i to on odpowiada jako sprawca główny. Ryzyko dla zajmującego się sprawami innej osoby odnosi się do uczestnictwa w sprawach gospodarczych, może oznaczać bycie częścią pewnej organizacji. Najlepiej ukazuje to przykład osób prawnych. Spółka kapitałowa jako organizacja nie może ponosić odpowiedzialności karnej, dlatego też za naruszenia prawa podatkowego odpowiadają określone osoby fizyczne, które w ramach tej organizacji zajmują się sprawami gospodarczymi, finansowymi. Spółka zawsze działa przez konkretne osoby, mimo że wszelkie działania wykonywane są w imieniu i na jej rzecz. Odpowiedzialność karnoskarbowa spoczywa na osobach, które przyjęły na siebie obowiązki z zakresu prowadzenia spraw gospodarczych, finansowych. Posiadanie różnych kompetencji wynikające ze złożonej hierarchizacji podmiotu lub jego skomplikowania, np. na linii pracownik działu księgowości - główny księgowy - dyrektor finansowy - członek 
zarządu, powoduje konieczność każdorazowego badania spełnienia przesłanek unormowanych $\mathrm{w}$ art. $9 \$ 3$ k.k.s. w granicach uprawnień, zachowań i przyjętych na siebie obowiązków każdej z tych osób. W przypadku zwykłych, szeregowych pracowników bez kompetencji decyzyjnych nie będzie mowy o spełnieniu przesłanek tej normy prawnej. Nie oznacza to, że nie mogą odpowiadać jako pomocnicy (Grzegorczyk, 2000, s. 121). O zajmowaniu się sprawami gospodarczymi będzie mowa w tych przypadkach, do których odnosi się uczestniczenie w sprawach gospodarczych tej osoby.

Nie ulega wątpliwości, że odpowiedzialność karna grozi za osobiste, własne zachowanie sprawcy, spełniające przesłanki czynu zabronionego. Czyn nie jest jednak pewnym wycinkowym, fragmentarycznym zachowaniem, ale jest rozumiany szerzej, z punktu widzenia funkcjonalności w kontekście przyjętych obowiązków i posiadanych kompetencji reprezentanta, a zatem w odniesieniu do powinności, jakie ciążą na nim.

\section{Zakończenie}

Artykuł $9 \$ 3$ k.k.s. reguluje odpowiedzialność osoby fizycznej będącej reprezentantem osoby zobowiązanej do przestrzegania norm prawa finansowego. Nie jest to wyodrębniony typ sprawstwa, a rozszerzenie kręgu osób, wobec których można wyciągnąć prawnokarne konsekwencje w przypadku naruszenia przepisów prawa karnego skarbowego i norm odsyłających. Ustawodawca przyjął model, w którym każdy sprawca odpowiada za swoje działanie, ale po to ustanowił tę szczególną kategorię sprawczą, aby lepiej chronić publiczne interesy skarbowe. Prawo karne skarbowe z uwagi na swoją specyfikę oddaje także typowo ekonomiczny charakter czynów zabronionych oraz subsydiarny charakter kodeksu wobec norm prawnych regulujących zagadnienia finansowo-podatkowe (Kaczmarek, 2004, s. 127-140). Gdyby nie instytucja opisywana w niniejszym artykule, w niektórych sytuacjach, nienależących do nielicznych, nie doszłoby do spełniania podstawowych funkcji prawa karnego skarbowego, takich jak funkcja kompensacyjna czy sprawiedliwościowa.

Reprezentowany odpowiada za przestrzeganie ciążących na nim obowiązków, działając w imieniu własnym i na swoją rzecz. Reprezentant zaś odpowiada za działalność prowadzoną w imieniu i na rzecz reprezentowanego, działając niejako w jego zastępstwie i w ramach jego funkcjonowania. Odpowiedzialność reprezentanta nie jest klauzulą służącą do przerzucania odpowiedzialności z jednej osoby na drugą. Sprawstwo reprezentowanego nie oznacza automatycznie 
sprawstwa reprezentanta, jednak bez określonego zachowania lub zaniechania reprezentowanego nie dojdzie do naruszenia norm prawa finansowego, co jest fundamentem odpowiedzialności osoby prowadzącej jego sprawy. Opisywana instytucja powołuje odpowiedzialność karnoskarbową tego, kto zajmuje się sprawami finansowymi określonego podmiotu zobowiązanego przez prawo finansowe do pewnych zachowań i to niezależnie od jej formalnego położenia w strukturze tej osoby lub poza tą strukturą. Odpowiedzialność reprezentowanego i osoby zajmującej się prowadzeniem jego spraw nie są wzajemnie zdeterminowane. Jeśli każda $\mathrm{z}$ nich swoim zachowaniem wypełnia model znamion, wówczas odpowiedzialność spoczywa na wszystkich osobach. Nie zmienia tego faktu, że obowiązki publicznoprawne osadzone w prawie finansowym ciążą na podatniku czy płatniku, nie na osobie prowadzącej jego sprawy.

Regulacja znajdująca oparcie w art. $9 \$ 3$ k.k.s. ma wprowadzać odpowiedzialność osób zajmujących się sprawami gospodarczymi innej osoby przy jednoczesnym braku tożsamości czynów, a nawet braku podmiotowości reprezentanta na gruncie przepisów nierozerwalnie związanych z blankietową normą kodeksu, który odnosi się do innych przepisów, np. prawa podatkowego. W ich reżimie reprezentant nie tylko nie jest odpowiedzialny za wywiązywanie się z obowiązków publicznoprawnych, lecz także w ogóle nie jest podmiotem tychże. Mimo tego ciąży na nim ryzyko zastępczej (ale jako sprawca) odpowiedzialności karnoskarbowej. Z drugiej jednak strony nie zachodzi odpowiedzialność reprezentanta, którego działania nie spowodowały negatywnych skutków w zakresie przestrzegania norm prawa finansowego, do których odsyła art. $9 \$ 3$ k.k.s., ponieważ działanie reprezentanta w imieniu innej osoby to zachowanie, którego skutki prawne odzwierciedlają się bezpośrednio w sferze prawnej tej osoby.

Istotne dla rozstrzygnięcia ryzyka narażenia na odpowiedzialność spoczywającego na osobie prowadzącej sprawy jest kwestia podstawy przekazania jej tych spraw, ustalenia obowiązków i wywiązywania się z nich, każdy bowiem odpowiada w granicach swoich obowiązków, lecz także wiedzy i staranności. Przedmiotowa odpowiedzialność odnosi się do osób fizycznych reprezentujących podmiot zobowiązany, mogących występować w tej roli na różnej podstawie lub nawet bez wyraźnego tytułu, per facta concludentia. Rozstrzygające jest tu jasne wyrażenie woli reprezentowanego określającego osobę reprezentanta i zakres jego obowiązków w granicach kompetencyjnych i przyjęcie ich przez reprezentanta. Instytucja $\mathrm{z}$ art. $9 \$ 3$ k.k.s. wypełnia potrzebę odpowiedzialności poszczególnych elementów łańcucha zachowań osób fizycznych, w którym każda osoba odpowiada za określone czynności w ramach prowadzenia spraw gospodarczych reprezentowanego. 
Przyjęty model ustawodawczy powoduje, że reprezentant jest narażony na odpowiedzialność poprzez swoją działalność na rzecz innej osoby, prowadząc czy uczestnicząc w sprawach gospodarczych, jednak znamienna pozostaje ocena świadomości reprezentanta np. przy dokonywaniu rozliczeń podatkowych. Świadomość celu wykonywanych przez niego czynności jest kluczową kwestią, której wystąpienie warunkuje przypisanie mu odpowiedzialności na opisywanej podstawie. Wykazywanie tej świadomości jest przy tym okolicznością trudną do udokumentowania, bowiem z prowadzenia spraw przyjmujących charakter zmaterializowany nie musi wynikać owa świadomość reprezentanta, może być to wywiązywanie się z obowiązków zgodnie z posiadanymi danymi i dokumentami. Reprezentant porusza się w granicach swojego umocowania oraz najczęściej opierając się na informacjach i dokumentach przekazanych przez reprezentowanego. Z tą problematyka mierzą się organy prowadzące postępowanie w kierunku ustalenia odpowiedzialności reprezentanta, przez którą trudno jest ustalić, kto jest sprawcą zarzucanego czynu zabronionego.

Odpowiedzialność reprezentanta nie zależy od decyzyjności tej osoby. Dokonywanie czynności technicznych czy rachunkowych przy świadomości celu objęte jest ryzykiem sprawstwa osoby prowadzącej cudze sprawy. Kluczowe jest branie udziału w sprawach gospodarczych, a zatem zachowanie reprezentanta w tych sprawach reprezentowanego. O odpowiedzialności reprezentanta nie przeważa indywidualny status podmiotu, ale charakter zachowania reprezentanta in concreto do każdego przypadku, bo jeśli uczestniczy on w popełnieniu czynu reprezentowanego, to także jest narażony na odpowiedzialność.

\section{Bibliografia}

\section{Akty prawne}

Ustawa z dnia 6 czerwca 1997 r. - Kodeks karny, Dz.U. 2019, poz. 1950, t.j. z 14.10.2019 r. Ustawa z 29 sierpnia 1997 r. - Ordynacja podatkowa, Dz.U. 2019, poz. 900, t.j. z 14.05.2019 r. Ustawa z 10 września 1999 r. - Kodeks karny skarbowy, Dz.U. 2020, poz. 19, t.j. z 8.01.2020 r. Ustawa z 28 lipca 2005 o zmianie ustawy - Kodeks karny skarbowy oraz niektórych innych ustaw, Dz. U. 2005, poz. 1479, t.j. z 16.09.2005 r.

Uzasadnienie do projektu Kodeksu karnego skarbowego, druk sejmowy nr 1146 z 1999 r. Pobrano z http://orka.sejm.gov.pl/Rejestrd.nsf/wgdruku/1146/\$file/1146.pdf (30.11.2020).

Uzasadnienie do projektu ustawy o zmianie ustawy - Kodeks karny skarbowy oraz niektórych innych ustaw, druk sejmowy 2375 z 2003 r. Pobrano z http://orka. 
sejm.gov.pl/Druki4ka.nsf/(\$vAllByUnid)/874BBF79908ACBA2C1256E05003C 6CE0/\$file/2375.pdf (30.11.2020).

\section{Orzecznictwo}

Postanowienie Sądu Najwyższego z 24 lutego 1999 r., I KZP 26/98, LEX nr 35638.

Uchwała Sądu Najwyższego z 26 kwietnia 2007 r., I KZP 7/07, OSNKW 2007/5/38.

Wyrok Sądu Najwyższego z 7 listopada 2013 r., V KK 158/13, OSNKW 2014/2/17.

Wyrok Sądu Najwyższego z 2 lipca 2002 r., IV KK 164/02, POP 2004/6/131.

Wyrok Sądu Najwyższego z 22 lutego 2006 r., III KK 213/05, OSNKW 2006/5/45.

Wyrok Sądu Apelacyjnego w Szczecinie z 31 października 2012 r, II AKa 176/12, LEX nr 1237935.

Wyrok Sądu Apelacyjnego we Wrocławiu z 25 kwietnia 2012 r, II AKa 101/12, LEX nr 1163706.

Wyrok Wojewódzkiego Sądu Administracyjnego we Wrocławiu z 16 października 2012 r., I SA/Wr 941/12, LEX nr 1248303.

Wyrok Wojewódzkiego Sądu Administracyjnego we Wrocławiu z 9 sierpnia 2013 r., I SA/ Wr 643/13, Lex nr 1366919.

\section{Literatura}

Grzegorczyk, T. (2000). Kodeks karny skarbowy. Komentarz. Warszawa: Wolters Kluwer Polska.

Kaczmarek, T. (2004). Z rozważań nad ekonomiczną teorią kary. Czasopismo prawa karnego i nauk penalnych, 2, 127-140

Dębski, R. (red.). (2013). Nauka o przestępstwie. Zasady odpowiedzialności. Warszawa: C.H. Beck.

Konarska-Wrzosek, V., Oczkowski, T., Skorupka, J. (2012). Prawo i postępowanie karne skarbowe. Warszawa: LEX.

Kotowski, W., Kurzępa, B. (2006). Kodeks karny skarbowy. Komentarz. Warszawa: LexisNexis.

Majewski, J. (2002). Tak zwana kolizja obowiązków w prawie karnym. Warszawa: Wydawnictwo UKSW.

Mering, L. (2007). Podmiot odpowiedzialności karnej za przestępstwo skarbowe. Glosa do Uchwały SN z dnia 26 kwietnia 2007 r., I KZP 7/07. Gdańskie Studia Prawnicze - Przeglą Orzecznictwa, 4, 135-142.

Nalikowski, F. (2011). Odpowiedzialność za działanie w cudzym interesie (art. $9 \$ 3$ k.k.s.). Państwo i Prawo, 2, 95-103.

Słownik Języka Polskiego. (2020). Podatek. Pobrano z https://sjp.pwn.pl/szukaj/podatek. html (30.11.2020). 
Słownik Języka Polskiego. (2020). Podatnik. Pobrano z https://sjp.pwn.pl/sjp/podatnik;2501947, (30.11.2020).

Tatarczak, P., Tatarczak, J. (2002). Odpowiedzialność karna skarbowa doradców podatkowych i księgowych. Monitor Podatkowy, 1, 24-28.

Tyszkiewicz, L. (1964). Współdziałanie przestępne i główne pojęcia z nim związane w polskim prawie karnym. Poznań: Wydawnictwo UAM.

Wilk, L., Zagrodnik J. (2019). Prawo i proces karny skarbowy. Warszawa: C.H. Beck. Zawłocki, R. (2013). Odpowiedzialność karna reprezentanta podmiotu zbiorowego. Warszawa: C.H. Beck.

\section{Streszczenie}

Niniejszy artykuł odnosi się do kwestii pociągnięcia do odpowiedzialności karnej skarbowej osoby prowadzącej sprawy gospodarcze, w szczególności sprawy finansowe innej osoby, na której spoczywają obowiązki ustanowione przez prawo finansowe. Przyjęcie do prowadzenia takich spraw w pewnych warunkach wiąże się z ryzykiem, ponieważ za ten sam czyn odpowiedzialność karną może ponosić kilka osób, a ewentualna kara wymierzona sprawcy nie depenalizuje zachowania innych osób. Zgodnie z obowiązującym Kodeksem karnym skarbowym za przestępstwa i wykroczenia skarbowe osoba odpowiada jak sprawca, jeżeli prowadzi cudze sprawy gospodarcze, w szczególności finansowe, na podstawie przepisu prawa, decyzji właściwego organu, umowy lub faktycznego ich wykonywania. Podstawa prowadzenia spraw nie jest decydująca, istotą odpowiedzialności jest przyjęcie na siebie obowiązków i ich wykonywanie w kontekście nakazów i zakazów ustanawianych w prawie finansowym.

SŁowA KLUCzowe: prawo karne skarbowe, odpowiedzialność karna skarbowa, prowadzenie cudzych spraw, prowadzenie spraw finansowych, podatnik, płatnik, sąd.

\section{Summary}

This article refers the issue of penal and fiscal liability of a person who manages someone else's affairs, in particular, the financial matters of a person who has obligations under financial law. Admission to conduct such cases under certain conditions is related to the risk of liability, because several people may be liable for the same act, and any punishment imposed on the perpetrator does not decriminalise the act of others. In accordance with the applicable penal fiscal law, such a person is liable for fiscal offenses as a perpetrator if this person manages other person's economic affairs, in particular financial ones, on the basis of a provision of law, the decision of a competent authority, a contract or the actual execution of financial management. The basis of managing other person's affairs 
is not decisive, the essence of liability is assuming responsibilities and performing them with regard to obligations and prohibitions which are applied in financial law.

KEYwORDs: penal fiscal law, penal fiscal liability, managing other person's affairs, managing financial affairs, taxpayer, payer, court.

\section{Nota o autorze}

Paweł Świder - mgr, doktorant przy Katedrze Prawa Karnego Materialnego i Kryminologii na Wydziale Prawa i Administracji Uniwersytetu Gdańskiego; główne obszary działalności naukowej: odpowiedzialność karnoskarbowa i błąd w prawie karnym skarbowym; e-mail: kontakt@ kancelariaswider.pl. 